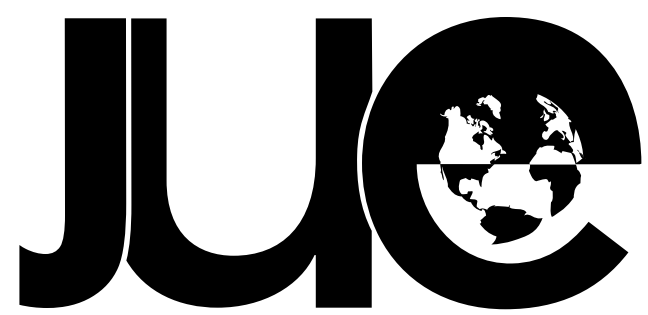

The Journal for Undergraduate Ethnography

Issue I. Spring 2011

\title{
Dumpster Dinners: An Ethnographic Study of Freeganism
}

Victoria C. Moré

ILLINOIS STATE UNIVERSTYY, VICTORIACMORE@GMAL.COM

\section{Abstract}

Dumpster Dinners: An Ethnographic Study of Freeganism at Illinois State University dives into dumpsters with the freegan subculture of Bloomington-Normal, Illinois. Freeganism is a way of life based on limited participation in the conventional economy and has been gaining popularity in recent years. Freegans strive to spend little money, barter or trade for goods and services, and live off food that has been thrown away. The freegans in this study are three motivated and educated women who regularly dumpster dive behind local businesses for food and products. Additionally, the freegans barter for goods and services and exhibit a "make it do or do without" attitude that seems almost obsolete in today's hyperconsuming America. This study explores where and why freegans exist, the process of turning garbage into groceries, why perfectly good groceries become garbage in the first place, and what can be learned from the freegan way of life. This study was conducted for an undergraduate senior thesis course in Anthropology at Illinois State University, spring of 20 I 0.

On a misty evening, Rex Sunnyside approaches a dumpster, turns on the flashlight, and takes a look inside. "Ooooh... it's really nasty!" As she moves the light around, familiar things appear. "Oh, wow, there's a mango... a pear... look, there's a pineapple... and a cantaloupe... but it looks pretty funky!"
Americans dispose of billions of pounds of food waste per year; much of it still fit for consumption. In a study by the USDA Economic Research Service, it is estimated that II.4 percent of fresh fruit and 9.7 percent of fresh vegetables per grocery store were lost due to inedibility from 2005-2006 (Buzby 2009:2). Unfortunately, supermarkets often toss these so-called "inedible" fruits and vegetables for superficial reasons. Some people, 
outraged by the "waste" grocers send to the landfill, have begun to salvage and eat it. These people, sometimes called "freegans", are "people who employ alternative strategies for living based on limited participation in the conventional economy and minimal consumption of resources." (Weisman, Freegan.info). "Freegan" is a combination of the words "free" and "vegan," although freegans are not necessarily vegans. Freegans expose the issue of food waste at a time when many of their neighbors--- some 49 million Americans, including I6.7 million children--live in food insecure households (Nord 2010:15).

In this paper, I describe a small group of young adult freegans living in Bloomington-Normal, Illinois, and compare these college-student freegans to others within the larger international freegan movement. I describe freegan activities such as dumpster diving, bartering, and repurposing to show the symbolic transformation of garbage into groceries.

\section{METHODS AND SETTING}

Data for this paper comes from ethnographic research (participant-observation) and interviews with three self-identified freegans. The general purpose of ethnographic research is to learn how people make sense of their own communities and to show how dimensions of a culture are interrelated (Rosen 2000:55). To learn about freeganism, I became a participant-observer in a group of freegans in Bloomington-Normal, Illinois.

Bloomington-Normal is a prosperous, white-collar community and is home to two universities. The freegans of this study were students or recent graduates of Illinois State University, a public university with 20,000 students. I had known two of the freegans, who I call Minnie Conrad and Rex Sunnyside, since our freshman year of college. Wimpy Oak, the third freegan, was introduced to me in January 2010 at the start of this project, which was conducted for my senior thesis in anthropology. As a freshman in 2006, I was aware that Sunnyside and Conrad sometimes attended school club meetings and art gallery openings for free food, and I heard them talk about there being "too much stuff in the world," but at that time I had rarely heard the words "freegan" and dumpster diving come up in conversations. In August 2009, Oak, Sunnyside, and Conrad started dumpster diving together regularly. Weekly potlucks were popular with our mutual friends, and Conrad showed up with dishes creatively titled "dumpster salad" or "hobo soup." Knowing exactly where the ingredients in her dishes came from, we would all have a good laugh, and then eat it with little hesitation.

As a participant-observer, I decided to become a freegan for one month. For that month, I did not spend any money on food; I ate food left over in my cabinets and food acquired while dumpster diving. In addition to six dumpster dives with the freegans, I participated in at least six on my own. In preparation for this experiment I bought a few staple items, such as spices, rice, lentils, and nuts. To reduce my overall participation in the consumer economy, I vowed to only use my car going to and from my internship and the dumpsters, nothing else. I also utilized a barter system to exchange goods. Additionally, I 


\section{These freegans demonstrate an extreme version of freeganism, separate from mainstream culture and live for free all the time.}

recorded and transcribed in-depth interviews with each of the 3 freegans, and recorded dialogue while dumpster diving.

As far as I know, there is no other group of people who call themselves freegans in the Bloomington-Normal area, though there are plenty of other people who dumpster dive to collect cans and scrap metal to sell. The student freegans described in this thesis are not part of a marginalized population, but instead dumpster dive voluntarily to reduce waste and protest overconsumption.

\section{FREEGANS: FORAGERS, ACTIVISTS, OR BOTH?}

Although freeganism has received attention from the press (multiple news stories, magazine and newspaper articles, radio shows, and a discussion on Oprah), few ethnographic studies of freegans exist. An exception, Joan Gross explores freegan foodways in rural Oregon and describes freegans as, "modern-day foragers who live off the waste of others and what they can gather in the wild" (Gross 2009:57). Gross conducted her ethnographic study among one freegan household and had informal conversations with four other foragers all in the small rural town of Alsea, Oregon. None of the foragers were active in the community or had a stable residence; they had all lived in 4-I5 places during one calendar year. In Alsea, they foraged in the wild, ate road kill, and took trips to the city to dumpster-dive. These freegans demonstrate an extreme version of freeganism, separate from mainstream culture and live for free all the time. The freegans in my study, in contrast, are employed, have professional goals and are active community members.
Gross points out that the freegans she knew had a strong sense of self-reliance and independence, without having a job or steady monetary income. In fact, the freegans saw paid work as "a kind of drug that sucked you in deeper and deeper" (Gross 2009:73). One freegan expressed, “...once you get into that cycle, paying rent and paying insurance on your car, you need money to keep those things going. So you're dependent on your job, and you're dependent on your car and your house... and it's like you're constantly spending money and never have enough..." Interestingly, interviews with other lowincome individuals who had a more conventional lifestyle seemed to agree with that point of view. According to Gross, those individuals ate both less nutritious and less enjoyable meals than the freegans (73).

Ferne Edwards and David Mercer (2007) describe a very different group of freegans in Australia. Edwards and Mercer interviewed 20 men and 10 women, from 18-58 years of age, with the majority being in their early 20 's. These people either “(i) practiced either DD [Dumpster Diving] or FNB [Food Not Bombs], (ii) practiced both activities, and (iii) one person who exclusively collected 'wasted' food put aside by supermarket and bakery staff in separate boxes and bags." (Edwards and Mercer 2007:282). Food Not Bombs is an all-volunteer organization that recovers food that would otherwise be thrown out, and makes fresh hot vegan and vegetarian meals served for free in public spaces. The authors found that people drawn to dumpster diving and FNB were predominately males in their mid 20's from welleducated middle-class backgrounds who had strong 


\section{Freegans may make other economic and lifestyle adjustments such as relying on barters, where one exchanges goods and/or services.}

ideological beliefs on which they based their lifestyle. They considered environmental and humanitarian aspects of where and how food was produced, and were aware of the ethics of food consumption. Some followed diets based on their convictions, including vegetarianism, raw foodism, or "veganic" (vegan and organic foods). Some also consumed road-kill, to "show animals the dignity that they deserve" (Edwards \& Mercer 2007:287).

These and other studies (Black 2007, Graeber 2004) show a range of freegan livelihoods and counterculture. To some, freeganism is an organized countercultural movement; the role of which as Gross notes "is to call into question behaviors that are taken for granted by mainstream society," (60). Globally it appears freegans are generally male, young, independent, and educated. They make a conscious effort to alienate themselves from capitalism and overconsumption.

Freegan activities, however, vary depending on personal attitudes and beliefs. Some simply ask store clerks to give them food about to be thrown away. Others might practice "plate scraping" or "table diving" by sitting at a restaurant (sometimes with staff permission) and finishing the food on people's plates after they leave (Freegan.info). Others live from foraging the generally ignored edible plants that grow all around us.
Freegan activities are not limited to obtaining food. Freegans may make other economic and lifestyle adjustments such as relying on barters, where one exchanges goods and/or services. Some freegans, motivated in part by strong anti-consumerist, anticorporate beliefs, may scam and shoplift from stores or take things from a workplace. Squatting, the practice of illegally occupying an abandoned space is practiced by some freegans, and many freegans bike, make their own clothing, buy second hand, organize free stores, and use websites like freecycle.org to trade goods. At another level, freegans may organize to use the waste for a greater social good such as donating it to shelters, or cooking and giving away free meals. Freegans in the UK, Australia, and New York City all have a very strong organized presence. They reach out to the public through the media and websites that explain how to freegan (such as New York based Freegan.info, which explains the freegan philosophy and organizes events to encourage individuals to meet other freegans in their area).

The freegans in Bloomington-Normal do not return items found in dumpsters, steal, plate scrape, forage in the wild, eat road kill, or continuously move from place to place. They do, however, barter, attend and organize free stores, and, as mentioned, dumpster dive for food and various other items. Conrad rides a salvaged bicycle, and both Sunnyside and Conrad alter and mend their clothing. 


\section{FREEGANS AT ISU}

The people in this ethnography are all educated females in their twenties. They either currently attend or have graduated from Illinois State University, and currently they all dumpster dive together regularly. Wimpy Oak, 26, feels that she has always been a bit of a freegan because of the way she was raised. "We could have survived without picking things up on the side of the road, but if it was useful, we took it." Later, Oak started reclaiming thrown away goods while living by herself in college.

Conrad and Sunnyside, both 21, would go around campus keeping an eye out for free things - like free food at club meetings or gallery openings - during their freshman year. When it came time for move-out from dorms and apartments for the summer, Sunnyside and Conrad saw for the first time how many hardly-used items were discarded as trash. Sunnyside explained that once she got to college, she realized "Wow. People get rid of a lot of stuff, and it's all useful." It is hard not to curb shop in college towns when items appear in such huge quantities.

Sunnyside's first time in a dumpster was with a friend she met through a religious student organization at ISU. The friend, also a female, had been dumpster diving before and after going with her once, Sunnyside's dumpster diving habit began. Sunnyside also believes that the way she was raised has an influence on her current lifestyle choice. "My grandmother doesn't throw out much; she knows everything that she has and how long she's had it... Also, growing up with four siblings we had to figure out how to make ends meet. We were resourceful and looked for options that were cheaper and free."

The ISU freegans use some terms regularly that are worth taking time to define. To "dive" is to go dumpster diving: "that dive was bountiful!" Also, they use the word "dumpstered" to describe items found in the dumpster: "The sauce has dumpstered peppers in it." Freegan is used as a verb:"This book was freeganed."

\section{INSIDE LOCAL DUMPSTERS.}

My first dumpster dive was a chilly Sunday evening in late January. I met the girls at their apartment and we prepared for the dive. To ensure safety while diving, the divers either wear rain boots (preferably) or old gym shoes. Clothing does not usually get too dirty, but this is no place for your favorite jeans. Gloves, preferably sturdy gardening gloves, are good protection from anything sharp or nasty. In colder months, warm gloves underneath the protective ones are a necessity, along with the usual winter layers.

At first glance, dumpsters look grim and smell unpleasant. Eventually, your eyes adjust and familiar items appear, such as zucchini buried under wilted lettuce, or an upside down box hiding carrots and oranges. Shuffling around some more could reveal a bag of apples or onions. It takes your breath away when you see the amount of food that is unblemished, amongst a few rotten apples. Usually, the amount of food is so abundant that the freegans can be picky about what to take home. 


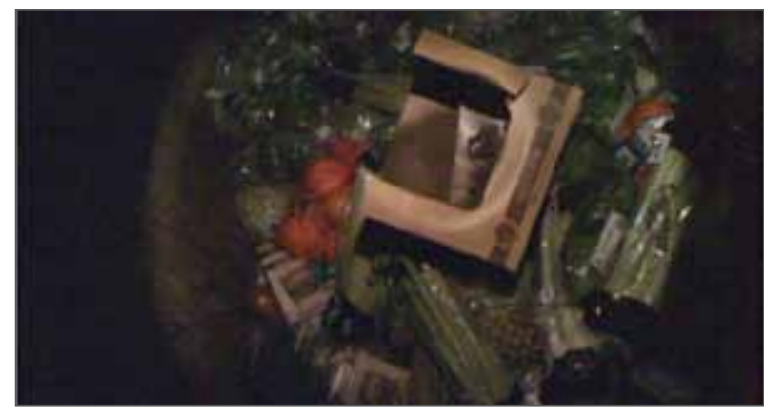

FIGURE I. PHOTO BY AUTHOR.

Unfortunately, there are bound to be garbage bags full of BBQ chicken wings and other meat products prepared and sold daily in the supermarket. These bags should be avoided as they are the source of the vile stench that wafts up from the dumpster and sticks to your clothing. Not all freegans would avoid this, though.

From observations, it is plain to see anything and everything in the produce department ends up in the dumpster at some point, even baskets used to display fruit.Apples, zucchini, pre-sliced fruit in containers, celery, bagged or boxed lettuce, carrots, and peppers are found quite frequently. Sometimes there are boxes of yogurt, bags of onions, oranges, grapefruit and potatoes, boxes of strawberries, asparagus, broccoli, tomatoes, jalapenos, poblanos, and specialty health juices. A solitary bruise is enough for a vegetable to get thrown away. One moldy orange, potato, apple, or onion in a bag of 12 is enough for the entire bag to be tossed. For some items there is no obvious reason for their disposal.

Some businesses have replaced dumpsters with trash compactors. Compactors increase the payload of the garbage trucks, making it economically beneficial. With the push of a button a store employee can destroy hundreds of pounds of "garbage." "Fresh Market,Walmart, Jewel, Meijer, Schnucks, they all have compactors so we can't go there," Conrad explained while we were on our first dive. It bothers Conrad to think that so much food and so many products are ruined in these machines daily.

Half-way into my first dive I was hooked. Initially I was shocked that we were pulling all of this nearly-perfect

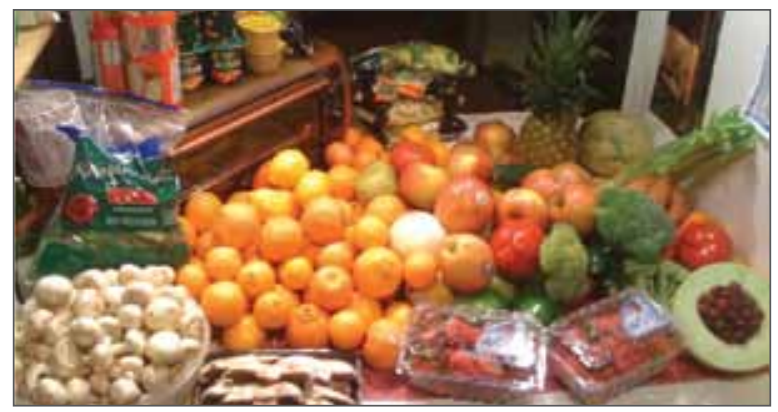

FIGURE 2. MY FIRST DUMPSTER DIVE JANUARY 26, 2010. PHOTO BY AUTHOR.

food out of a dumpster. Once we got to the second store, I was excited. It was thrilling to do something rebellious. This feeling of excitement grew when we got home and unloaded the car. Going up their apartment building stairs, we each had our arms full of heavy bags.

\section{HOW GARBAGE BECOMES GROCERIES.}

Once in the apartment, we put music on and began cleaning. With a sink full of soapy water, we started dunking veggies to get them clean, and to get rid of the faint lingering dumpster odor. Some, like Conrad's mother for example, insist that dumpsters are dirty and diseased, and express concern for the welfare of the dumpster divers. The mere fact that the food has been pulled from a dumpster tarnishes the image of the food inside it, no matter how pristine. Anthropologist Mary Douglas in Purity and Danger shows us that uncleanliness, or dirt, is matter out of place. "Dirt is the by-product of a systemic ordering and classification of matter, in so far as ordering involves rejecting inappropriate elements" (36). As hair isn't "gross" until it's detached from your head and found somewhere it shouldn't be, food in a dumpster is classified garbage because its location has changed. Waste is always a part of a classification system that arbitrarily designates what is pure and impure (Coyne 2010:2).

The almost pathological fear of germs that dominates American culture could also explain peoples disgusted reactions. Nancy Tomes, author of The Gospel of Germs argues this fear comes from bacteriological discoveries in the late 19th century, and has been exacerbated by the marketing of disinfectants and hygiene products. The 


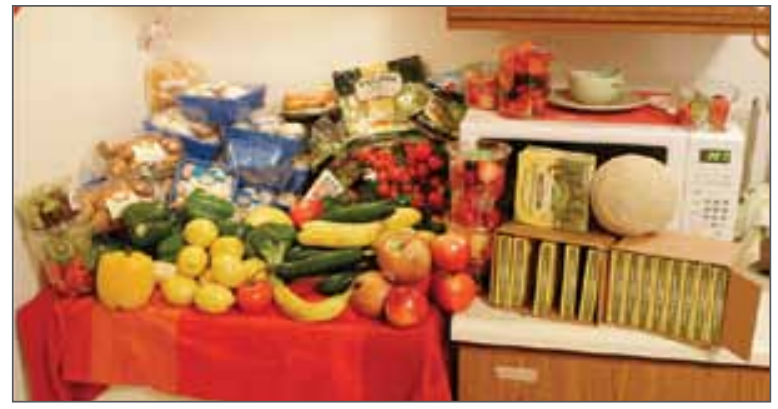

FIGURE 3. FEBRUARY 23, 20I0. PHOTO BY AUTHOR.

concerns from Conrad's mom and society in general do not discourage the freegans at all. None of them have ever gotten sick from dumpstered foods. Freegans challenge our hegemonic "throw away" culture by interchanging the meaning of waste and food, insisting that found items are in fact still pure.

During the cleaning process, the plastic that wraps many of the items is thrown away, spoiled food is put in a container to be composted, and plastic containers that are reusable are washed and put away. After each veggie had a good scrub, we set them up to dry on the counter where, for purposes of this ethnography, we arranged our findings for a picture. Once the work was done and I saw the giant pile of beautiful food (see figure 2), I was changed. Clearly, some of what we label 'garbage' is far from it.

One trip to the dumpster can bring in the equivalent of \$100-200 worth of food. One dive, on February 23, 2010 , yielded $\$ 138$ worth of groceries (see figure 3). This included boxes of guacamole, 28 zucchini, 14 wrapped containers of mushrooms, II bundles of radishes, and 10 bell peppers, lemons, fruit, lettuce, bread, broccoli, etc.

Another trip, on March 14th, yielded 3 bunches of bananas, 10-12 peppers (yellow, green, red), grapefruits, sliced pineapple, 12 containers of strawberries, I peeled watermelon, 2 IOlb bags of potatoes, 12 containers of fruit, 3 bags of onions, 6 boxes of lettuce, cherry tomatoes, 3 eggplants, I mini watermelon, I yellow squash, 6 bouquets of flowers, green grapes, boxes of salad, I box of blueberries, sweet potatoes, cauliflower, 7 celery, I bag of

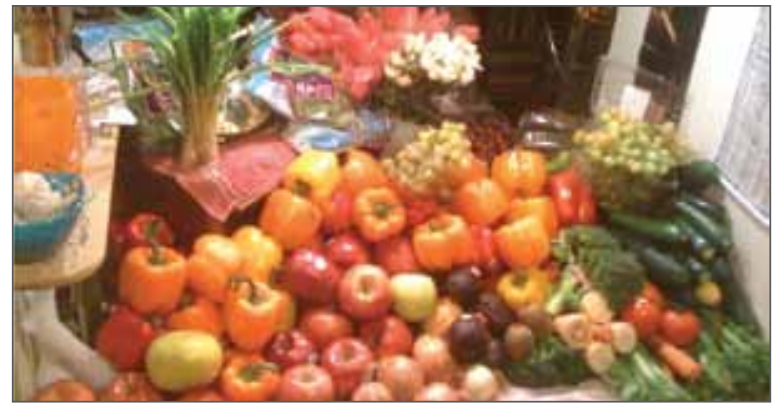

FIGURE 3. PHOTO BY AUTHOR.

apples, 3 bags flaxseed wraps, I box of fresh organic sage, carrot juice, and I orchid. The freegans often dubbed an item the Most Valuable Pick of the night. March 14th's MVP was definitely the orchid. Sunnyside stated, "I think we all decided that the best thing about [dumpster diving] is that you crave it. It turns into a scavenger hunt that is a surprise every time. It's enjoyable."

Although dives often bring a large amount of food, there are items that the freegans buy because they rarely if ever find it in the dumpster. These items include nuts, soymilk, peanut butter, olive oil, flour, and other baking ingredients.

Now that the found food is clean, it needs to be cooked into delicious dishes. Since grocery stores will throw away a large amount of the same item, the challenge becomes to use these ingredients before they spoil. Various preservation techniques are utilized to keep the food from going bad. Surpluses of fruit, like strawberries, cantaloupe, or blueberries, are frozen and used for breakfast smoothies. Grapes and bananas found in the dumpster are often on the softer side, and make a perfect frozen treat. One night we found 19 large containers of mushroom caps and portabella slices, so I learned how to freeze mushrooms. Loaves of bread and breakfast pastries are easily frozen and thawed, and fresh herbs can be dried.

Creative cooking can lengthen the life of the ingredients. One night we found 30 bell peppers (see figure 4) so I roasted 10 of them and had a beautiful jar of roasted red and yellow peppers. Other times there would be an abundance of grapefruits, broccoli, or 


\section{After that lengthy life food has had before it appears on our shelves, we foolishly expect the items to look perfect.}

zucchini. These "problems" encourage the freegans to experiment with soups, breads, and juices. "In general I feel I cook more than the average college student. I think we do more 'across the board' functions in the kitchen," said Sunnyside. Sunnyside, Conrad, and Oak all expressed that they are eating more healthily now than ever before. "Most of the time it's fresh, we are cooking at home, utilizing all the ingredients to the fullest. We make apple sauce out of apples, you know?" Additionally, finding this food in a dumpster makes you want something different to come of the food. If it goes to waste, then it goes to waste, but we tried as hard as possible to use every last bit.

It became apparent early on that Sunnyside, Conrad and Oak enjoyed sharing food with others. Any extra food from our dives (which was often the case) would be given to neighbors, friends, family, or the local food pantry. Since there was no monetary exchange labeling the food as exclusively theirs, sharing was part of almost every dumpster dive.

\section{HOW GROCERIES BECOME GARBAGE.}

Picking out produce at the grocery store engages ones sense of sight to avoid imperfections, touch to determine a good firmness, and smell to gauge ripeness.

Most Americans begin their relationship with fruit and vegetables when it is finally ripe. Prior to arrival at the store, the fruit has had a long life and possibly traveled a long distance.

Take an apple, for example.The apple was grown in an orchard (possibly in Washington, Michigan or California), picked, and sent to a controlled atmosphere (CA) warehouse where oxygen, temperature, and humidity are monitored so the fruit is kept alive, but does not ripen any further. It is then transported and stocked on the shelves of your local supermarket."Today, the Washington apple industry has more storage CA capacity than any growing industry in the world," Timothy Jones states in the 2005 article "Hallmark of a Sustainable Farming Industry." These warehouses limit waste of apples in the production process and allow apples to be cheap year round. While the benefits are apparent, the fact that we find apples in the dumpster almost every time we dive shows that a lot of this energy spent preserving the apple prior to their arrival at the supermarket goes to waste. Thus, it is not only food being wasted, but also fertilizer, water, soil nutrients, pesticides, herbicides, diesel, and gasoline (Jones 2006). What about the foods that travel an even greater distance? Some grapes come from Chile, some kiwis come from New Zealand, some mangoes are shipped from the Philippines, and many avocados come from Mexico only to end up in the garbage.

Our detachment has blurred what is important when getting food. Consumers are very concerned with cosmetic qualities when choosing produce. After that lengthy life food has had before it appears on our shelves, we foolishly expect the items to look perfect. No one is about to spend his or her hard-earned money on produce that has a blemish, or is in some way sub-par. For this reason, stores are pressured to supply produce that meets our unreasonably high standards. Edible food that is deemed unworthy of our dollars is sent to the dumpster. 
Additionally, "use by" and "best before" dates are often treated as expiration dates. The word expiration means the finish of something; ending, expiry, death. These words describe very little of the food in the dumpsters. Freegans trust their senses to tell them if food is edible or not, similar to anyone determining the quality of food in their own refrigerator. Freegans believe "sell by" and "use by" are not safety dates, but rather dates to keep the circulation of food on the shelves constant. The innate value of food is overlooked in the current system; monetary value seems to be all that matters. Sadly, it seems stores can't or don't try to eliminate food waste. Employees are not allowed to take food home, and expired food cannot be donated because of legal risk.

Besides a separate dumpster for corrugated cardboard, there is no attempt made by stores to recycle. Some of the packaging we find even says "please recycle," "compostable," or "biodegradable," but the stores probably consider the sorting process too much of a hassle. One night we ironically found re-useable grocery bags with the words "[name of store] Recycles!" in the dumpster. The same night we uncovered what we think was the lost-and-found, which contained hats, gloves, scarves, sunglasses, coffee mugs, jewelry, and a sweater (note: these items were found on a blistery cold night in mid-January). Sliced fruit in containers are regular finds (seen on the left side and near the microwave in figure 3) so the freegans save these and therefore have a seemingly unlimited amount of re-useable plastic containers for leftovers. Similarly, it is not uncommon to find food that come with bags, rubber bands, and twist-ties that can be re-used. The freegans eat the food they find, compost the food they don't, and reuse or recycle the packaging, showing us how little of the garbage is actually useless. As for the lost-and-found clothes? They went to the local homeless shelter.

And to think: This was all one step away from the landfill. The 2010 Illinois Commodity/Waste and Characterizations study estimates the market value of the stock of materials currently in landfills in Illinois, if they could be recovered, would be about $\$ 600$ million, and I doubt that number includes food. Timothy Jones conservatively estimates that the U.S. economy loses 90 billion dollars when retail, farm, and residential losses are added up.

Our food supply is the "most varied and abundant in the world, choosing from an average of 50,000 different food products on a typical outing to the supermarket" (Kantor 1997:I). The perishable fraction of that number is what gets thrown out most often. 'Food deserts' exist in poor urban neighborhoods and small rural towns where the only place to get food is the local gas station or convenience store; neither of which has anything nutritious to offer. Healthy food is also unattainable to many because of cost. This makes me wonder why the healthiest, priciest food is also the food most often thrown away.

Moreover, it is not grocery stores that are gaining popularity today; supercenters are. These massive stores house many more items than grocery stores, therefore throwing away more as well. "One-stop 
shopping is still a growing consumer appeal, practiced by half of US consumers, who now can find practically all their household requirements under one roof," (Seth 1999:197). The presumably massive amounts of waste produced by these mega-stores are destroyed without any hope of reclamation due to their use of garbage compactors.

\section{IDENTITY \& WAY OF LIFE}

Although Oak, Conrad, and Sunnyside do consider themselves freegans, none participate full-time. They pay rent, pay for cell phones, attend a university (Sunnyside and Conrad), have a full-time job and drive a car (Oak). That said, when asked if they would be freegans for life, all of them replied with a confident "yes." Oak added that she might practice on a different level, maybe not always dumpster diving, but will always reclaim things and buy second hand. Additionally, the ISU freegans do not consider themselves anti-consumerists, but rather conscious consumers. They do participate in purchasing things like the rest of us, but do so much less frequently and with much more awareness than many Americans.

Freegans are committed to lengthening the life cycle of everything that comes into their lives, not just food. They don't believe in buying new, and try not to buy anything at all. This means they repair clothing, their bicycles, and anything else instead of throwing it away. They always seem to find new uses for old items and demonstrate a "Use it up, wear it out, make it do or do without" attitude.Although this mind-set seems obsolete within the younger generation, it is a philosophy which our parents and grandparents grew up with. Some activities that exhibit this attitude include re-using birthday cards by drawing pictures over someone else's writing, catching the dripping runoffs of a candle into another dish and adding a wick, using pencil for making flash cards for school so they can be erased, Minnie Conrad even usesthe plastic packaging her USB drive came in as its carrying case.

The freegans barter regularly with friends. Bartering fits well with the freegan life since they are so focused on the use-value of items as well as community building. "If we barter say potatoes for shoes, both of these items will have diminishing marginal utility for us, i.e. the more we have of them the less useful they will be each additional amount" (Humphrey and Hugh-Jones 1992:9). The freegans believe bartering inspires participants to reach out to other people instead of stores for things they need. This gives value to an individual's talents, skills, and objects since such services and goods can be traded.

From Gross' article, the other ethnographic studies, and the media, it seems as though most freegans are male or females with males accompanying them. Only once did I ever come across an article solely about freegan girls, setting the ISU freegans apart. All three of them are strong, motivated, and independent women who believe in making a positive impact in the community around them. Not only are they female, but also they became freegans from the influence of other female freegans.

Dumpster diving, though fruitful, takes longer than a trip to the grocery store. Including traveling and cleaning, one dive could take 2-3 hours, and is also quite labor 


\section{One of the biggest differences between freegans and the rest of society is their perspective of value.}

intensive. With little or no processed foods like Easy Mac or Ramen in their diet, cooking takes up more time than some students would be willing to spend.

Sunnyside and Oak see freeganism as an extension of their Christian religion. They believe that God gave humans the earth and therefore it should be respected. Sunnyside stated, "There is more of a circle involved in life, we just have to figure out how to get in that cycle and make [our food system] a connected circle instead of a disjointed line." Minnie Conrad chooses not to align with a particular religious outlook, but agrees that, "the cycle is so complete and perfect, why would you mess with it?" referring to the cycle of nature.

One of the biggest differences between freegans and the rest of society is their perspective of value. They do not only see value in terms of how much money it is "worth," but also in terms of its basic qualities and potential to be repurposed. Freegans try to live morally in a society and economy that they perceive as largely immoral."To think about the relationship of morality and economics is to connect the most abstract and perhaps meaningful realm of human life with the most banal-to consider how the everyday matter of living agents gets infused with our deepest beliefs of what we live for and how we live well” (Browne 2009:2).

\section{CONCLUSION}

Freeganism uncovers how much is wasted around us every day. Living in a culture that allows food to be thrown away thoughtlessly is an enormous statement about what is considered sacred and important. Grocery stores seem to only pay attention to the monetary value of food and ignore its intrinsic value. Robin Nagle is the anthropologist in residence at the New York Department of Sanitation, and I believe she said it right when she said, "Why have we found ourselves implicated in a system that not only generates so much trash, but relies upon the accelerating production of waste for its own perpetuation? Why is that OK?"

Freegans live a life that is creative; giving life to goods viewed by most as unusable. Instead of trying to make money to spend it, they strive to make less, spend less, and make the most out of what is available. Innovation and resourcefulness are qualities that individuals, companies, and countries should all strive for, and the freegans are experts. Freeganism allows the participant to step back and question practices otherwise considered normal, and helps us remember that even within our own communities there are alternative ways of life. To quote American anthropologist Laura Nader, "We have as anthropologists studied the cultures of the world to find in the end that ours is one of the most bizarre of all cultures."

This work is licensed under a Creative Commons Attribution-NonCommercial-NoDerivs 3.0 Unported License. 


\section{BIBLIOGRAPHY}

Black, Rachel. Eating Garbage: Socially Marginal Food Provisioning Practices. In Consuming the Inedible: Neglected Dimensions of Food Choice. Jeremy MacClancy ed. NewYork: Berghahn Books, 2007

Browne, Katherine E., and Barbary Lynne Milgram. Economics and Morality:Anthropological Approaches. United Kingdom: Rowman Altamira, 2009

Buzby, Jean C., Hodan Farah Wells, Bruce Axtman, and Jana Mickey. "Supermarket Loss Estimates for Fresh Fruit, Vegetables, Meat, Poultry, and Seafood and Their Use in the ERS Loss-Adjusted Food Availability Data." United States Department of Agriculture Economic Information Bulletin no.44 (March 2009): I-20

Coyne, Michelle. "From Production to Destruction to Recovery: Freeganism's Redefinition of Food Value and Circulation.” lowa Journal of Cultural Studies. (2009) http://www.uiowa.edu/ ijcs/waste/coyne.htm

Douglas, Mary. Purity and Danger:An Analysis of the Concepts of Pollution and Taboo. Arc Paperbacks, 1966

Edwards, Ferne and David Mercer. "Gleaning from Gluttony: an Australian youth subculture confronts the ethics of waste.” Australian GeographerVol. 38, no.3 (2007): 279-296

David Graeber. Toward an anthropological theory of value: the false coin of our own dreams.

New York:Palgrave, 200I

Gross, Joan. "Capitalism and its Discontents: Back-to-the-Lander and Freegan Foodways in Rural Oregon." Food and Foodways Vol I7(2009):57-79.

Humphry, Caroline, and Stephen Hugh-Jones. Barter, Exchange, and Value:An Anthropological Approach. New York: Cambridge University Press, 1992

Jones, Timothy.“Hallmark of a Sustainable Farming Industry.” BioCycle vol.46, no.I I (November 2005):54

Jones, Timothy. “What to do about Food Loss.” BioCycle vol. 47, no. 7 (July 2006):32,34

Kantor, Linda, Kathryn Lipton, Alden Manchester, and Victor Oliveira. Estimating and Addressing America’s Food Losses. Food Loss. Washington D.C.:U.S. Department of Agriculture, 1997 
Nord, Mark, Margaret Andrews and Steven Carlson. Household food security in the United States, 2005. Washington D.C.: U.S. Department of Agriculture, Economic Research Service, 2006

Rosen, Michael. Chapters in Organizational Ethnography:Turning Words Spinning Worlds. Amsterdam: Overseas Publishers Association, 200I

Seth, Andrew, and Geoffrey Randall. The grocers: the rise and rise of the supermarket chains. United Kingdom:Kogan Page Publishers, 200I

Tomes, Nancy. The Gospel of Germs: Men,Women, and the Microbe in American Life. Cambridge, Massachusetts: Harvard University Press, 1988

Weissman, Adam. N.d. http://freegan.info/.Accessed February I, 2010 